\title{
A!
}

This is an electronic reprint of the original article.

This reprint may differ from the original in pagination and typographic detail.

Huttunen, Kristiina; Møen, Jarle; Salvanes, Kjell G.

\section{Job loss and regional mobility}

Published in:

Journal of Labor Economics

DOI:

$10.1086 / 694587$

Published: 01/04/2018

Document Version

Publisher's PDF, also known as Version of record

Please cite the original version:

Huttunen, K., Møen, J., \& Salvanes, K. G. (2018). Job loss and regional mobility. Journal of Labor Economics, 36(2), 479-509. https://doi.org/10.1086/694587

This material is protected by copyright and other intellectual property rights, and duplication or sale of all or part of any of the repository collections is not permitted, except that material may be duplicated by you for your research use or educational purposes in electronic or print form. You must obtain permission for any other use. Electronic or print copies may not be offered, whether for sale or otherwise to anyone who is not an authorised user. 


\title{
Job Loss and Regional Mobility
}

\author{
Kristiina Huttunen, Aalto University School of Economics \\ and Institute for the Study of Labor (IZA)
}

Jarle Møen, Norwegian School of Economics

Kjell G. Salvanes, Norwegian School of Economics

\begin{abstract}
We study the migration behavior of displaced workers and find that job displacement increases regional mobility. We find, however, that noneconomic factors, such as family ties, are very important for the migration decision and that there is strong heterogeneity in outcomes. We find large income losses for workers who move to regions where they have family or to rural areas, while, for example, rural to urban movers realize a significant long-term earnings increase. We also find that life events related to fertility, divorce, and new relationships correlate with mobility after job loss and may partly explain the large income losses.
\end{abstract}

\section{Introduction}

A long-standing puzzle in economics is why there are persistent differences in employment and earnings across regions (Blanchard and Katz 1992). Regional-specific shocks, such as increased international trade with

We thank Sandy Black, Matti Sarvimäki, and Steve Trejo; seminar participants at the Norwegian School of Economics, the University of Austin, Aalto University, and Jyväskylä University; and participants at the Society of Labor Economists meetings in Seattle and the European Association of Labour Economists meetings in Ljubliana. Kristiina Huttunen gratefully acknowledges financial support from the Finnish Academy. Kjell G. Salvanes and Jarle Møen thank the Research Council of Norway through its Centres of Excellence scheme (FAIR project 262675) for financial support. Contact the corresponding author, Kjell G. Salvanes, at

[Journal of Labor Economics, 2018, vol. 36, no. 2]

(C) 2018 by The University of Chicago. All rights reserved. 0734-306X/2018/3602-0005 $\$ 10.00$

Submitted December 24, 2014; Accepted September 30, 2016; Electronically published February 6, 2018 
China and other low-cost countries, may have increased regional differences further over the past 2 decades. ${ }^{1}$ Economists have also speculated that regional mismatch is a reason for the increased natural unemployment rate in the United States following the Great Recession. ${ }^{2}$ Why do more workers not relocate? Another question not well understood is why workers who have lost their jobs in plant closures or mass layoffs suffer significant and long-lasting employment and earnings losses. ${ }^{3}$ One possible explanation for both puzzles is that workers are immobile and face restrictions in their job search. Understanding the factors that determine migration is therefore important for policy makers developing policies for regions that face adverse economic shocks.

The costs of moving may vary as a result of family commitments, networks, and preferences regarding local amenities. While the literature on both migration and job displacement is large, we know little specifically about the migration behavior of displaced workers and how they fare in the labor market. Little is also known about how location-specific amenities, such as family ties, affect mobility. If workers make large trade-offs between income losses and the distance to their extended family, pure earnings analyses may overestimate the negative welfare effect of economic shocks for movers. We aim to fill these gaps in the literature by analyzing the mobility behavior and earnings of workers who have lost their jobs in plant closures and mass layoffs in Norway.

We ask three primary questions. First, what is the effect of job loss on the likelihood of moving? Second, what determines the choice to move after a job loss? Third, do earnings losses after job loss differ between movers and stayers? In the first part of the paper, we address the first two questions. We measure the effect of job displacement and background characteristics on the probability of relocation between regional labor markets in Norway, and we assess specifically the effect of family networks in the region where the workers lose their jobs and in the region to which they move. ${ }^{4}$

In the second part of the paper, we compare displaced movers and displaced stayers with a control group of nondisplaced workers by means of

kjell.salvanes@nhh.no. Information concerning access to the data used in this paper is available as supplementary material online

${ }^{1}$ See Autor, Dorn, and Hanson (2013) for an analysis of the impact of trade with China on regional labor markets in the United States, and see Balsvik, Jensen, and Salvanes (2015) for an analysis of the impact in Norway.

${ }^{2}$ Kroft et al. (2016) analyze the increased long-term unemployment rate in the United States following the Great Recession.

${ }^{3}$ See, e.g., Jacobson, LaLonde, and Sullivan (1993), Eliason and Storrie (2006), Schmieder, von Wachter, and Bender (2009), Rege, Telle, and Votruba (2009), Couch and Placzek (2010), and Huttunen, Møen, and Salvanes (2011).

${ }^{4}$ It is well established that family ties influence workers' mobility decisions (Mincer 1978). Alesina et al. (2015) show that individuals who inherit stronger family ties are less mobile, have lower wages, and are less often employed. 
the standard fixed effects framework. Since migration is a household decision, we assess family income as well as individual income. Our aim is to understand how much moving affects labor market outcomes after job loss and whether movers tend to be positively or negatively selected on unobservables. Theory predicts that workers move for various reasons after job loss. Job loss affects the costs of moving, but the moving decision is also influenced by economic gains and preferences for location-specific amenities, such as living close to other family members. Observed changes in income following migration are therefore not necessarily caused by the move itself. To better understand the sources of earnings differences between movers and stayers, we explore heterogeneity across workers in terms of their opportunity costs and the characteristics of the location that they stay in or move to. Mobility decisions after job loss will also be affected by events related to health and family formation. Such events can influence labor market outcomes and may be correlated with job loss. ${ }^{5}$ In the final part of the paper, we therefore analyze the development of fertility, disability, divorce, and cohabitation for displaced movers and stayers.

Key to our analysis is a long panel of linked employer-employee data that allows us to follow individuals even when they leave the labor force. By analyzing earnings and employment patterns several years prior to job loss, we can assess selection into mobility in a transparent way. Another unique feature is that we have information on spouses, children, and the location of parents and siblings as well as on disability and fertility.

We find that job displacement increases regional mobility, but workers with parents and siblings in the region are less likely to move than others. We also find that displaced workers who move are very heterogeneous. Migrants seem to be drawn disproportionately from both the high and the low end of the skill distribution in the region they leave. Movers are also more likely than stayers to have children after job loss, become divorced, or start cohabiting with a new partner. This is in line with our theoretical framework.

When analyzing the postdisplacement outcomes of movers and stayers, we find that displaced workers who move have significantly lower reemployment rates than those who stay on in the predisplacement region. Our fixed effects estimation results also indicate that displaced movers have larger earnings and family income losses than displaced stayers and that the difference is larger for women than for men. When splitting the sample by postdisplacement regional status, we find that the earnings losses associated

${ }^{5}$ See Lindo (2010), Del Bono, Weber, and Winter-Ebmer (2012), and Huttunen and Kellokumpu (2016) on fertility; Charles and Stephens (2004) and Eliason (2012) on divorce; and Sullivan and von Wachter (2009), Browning and Heinesen (2012), and Black, Devereux, and Salvanes (2015) on health. 
with migration is entirely driven by workers moving to rural regions and workers moving to a region where they have family. This suggests that noneconomic reasons strongly influence the moving decision and, in particular, that workers are willing to suffer earnings losses in order to stay close to their families.

Even though a large literature has examined the effect of job displacement on outcomes such as earnings, employment, health, fertility, and children's schooling, no previous study has explicitly documented how job displacement affects regional mobility and how workers select into mobility after permanent job loss. ${ }^{6} \mathrm{We}$ are also the first to analyze how postdisplacement earnings and employment patterns differ between movers and stayers while accounting for the predisplacement differences between the groups. ${ }^{7}$

The rest of the paper is organized as follows: Section II describes our theoretical framework. Section III describes the data sets. Section IV lays out the empirical strategy. Section V presents evidence on how job loss influences workers' migration decisions and what factors affect selection into migration after job loss. Section VI presents results on how job displacement affects labor market outcomes and how these outcomes vary between movers and stayers. Section VII concludes.

\section{Theoretical Framework}

The standard human capital framework predicts that a worker or family will move if the net returns of doing so exceed the costs. The traditional migration literature views the returns as pure economic gains at the individual or family level (Sjaastad 1962; Mincer 1978). The costs depend on the local labor market situation, family ties, and unobserved components. The standard model predicts that young workers are more likely to move due to their long amortization period and that highly educated workers are more likely to move due to their potential for high economic gains. The moving propensity for families decreases with family size, since returns increase less

${ }^{6}$ There is a large literature examining the relationship between general unemployment and migration; see, e.g., Pekkala and Hannu (2002) and the review by Greenwood (1997). Being unemployed increases individuals' likelihood of moving away from the region (see, e.g., DaVanzo 1978; Pissarides and Wadsworth 1989), and aggregate employment tends to be positively correlated with in-migration. Saks and Wozniak (2011) show that migration in the United States is procyclical. They assume that increases in aggregate wages generate procyclical migration, as creditconstrained workers can then finance their moves. Gregg, Machin, and Manning (2004) present evidence showing that unemployed workers in Britain are unlikely to move without first having a job.

${ }^{7}$ Boman (2011) provides some descriptive evidence on how postdisplacement earnings differ between displaced movers and displaced stayers in Sweden, but there is no attempt to document or control for selection into mobility. Like us, he finds that movers tend to earn less than nonmovers in the years following the move but that the difference fades away over time. 
than costs. When comparative advantage is taken into account, predictions about who moves are not so clear. The Borjas-Roy model shows that selection is based on relative returns to skills in the local labor market migrants move from and the one they move to. ${ }^{8}$ Labor markets with higher returns to skills will attract migrants who were relatively more highly skilled in their previous labor market, while labor markets with lower returns to skills will attract migrants who were relatively lower skilled in their previous labor market. It may then be that high-skilled workers are best rewarded in the same labor market that they are displaced from. ${ }^{9}$

The central idea of the approaches discussed so far is that job opportunities drive mobility decisions. Other strands of the literature suggest that the decision to move is affected by location-specific amenities. These amenities could be access to cultural events in urban areas, but they also could be nature and clean air in rural areas. Moretti (2011) extends the Rosen-Roback spatial equilibrium model of Roback (1982) to heterogeneous workers in terms of tastes for amenities. His model suggests that individuals differ with respect to preferences for these local amenities and that these differences can explain worker selection into mobility after local shocks. The presence of extended family members can be thought of as one such amenity that affects both the cost of moving and the expected gains. ${ }^{10}$ Parents are important and may affect mobility through several channels. People in general enjoy the company of their families, parents may influence workers' employment and earnings directly through their networks, parents may help bring up grandchildren, or parents may be elderly and in need of care. ${ }^{11}$ Siblings may represent a positive incentive for colocation for much the same reasons as parents, but having siblings can also make it easier to move away from elderly parents since siblings are substitute caretakers. ${ }^{12}$

${ }^{8}$ See Roy (1951), Borjas (1987, 1991), Borjas, Bronars, and Trejo (1992), and Abramitzky, Boustan, and Eriksson (2012).

${ }^{9}$ Migration may also be modeled as a dynamic job search problem (Kennan and Walker 2011). Workers move in search of a better locational match when the income realization in the current location is unfavorable. The dynamic approach allows for both home bias and a reduced cost of moving to a previous location.

${ }^{10}$ As far as we know, no one has estimated people's willingness to pay for proximity to their family. Hedonic regression studies explaining the differences in average wages across locations show, however, that households are willing to pay substantial amounts for other location-specific nontradable quality-of-life amenities, such as climate and public services. See Blomquist, Berger, and Hoehn (1988), Gyourko and Tracy (1991), and Chen and Rosenthal (2008). This suggests that the willingness to pay for proximity to family may also be high.

${ }^{11}$ See Lin and Rogerson (1995), Glaser and Tomassini (2000), Alesina et al. (2015), and Kramarz and Skans (2014).

${ }^{12}$ See Konrad et al. (2002) and Rainer and Siedler (2009). These papers do not assess migration as such but analyze proximity between siblings and parents. In these models, older children may act strategically and migrate away from parents in need of care. 
The job loss of a worker or his spouse affects migration propensity by exogenously decreasing the opportunity costs of moving. Job loss causes the opportunity cost to fall because there is no longer any job-specific capital to lose and no wage to forgo. Workers will then recalculate the optimal location choice and take into account both economic gains and location-specific amenities. Theory suggests that the opportunity costs of moving differ between workers, which implies that observed postmigration earnings are not necessarily causal effects of mobility. This is so even if migration is triggered by exogenous job loss. To better understand this, consider first a displaced worker that is forced to move in order to find suitable employment because of a high unemployment rate in the region and industry from which he or she was displaced. The subsequent change in income relative to a stayer with similar human capital is then a result of the move itself. Consider next a worker who for personal reasons has wanted to move to another location for some time but who has stayed on because the opportunity costs of moving are too high. When such a worker is displaced, the opportunity cost of moving is reduced, and the optimal location may change. A move is in this case motivated by location-specific amenities rather than wage gains, and the change in income relative to a stayer with similar human capital is not a causal effect of migration. Causal interpretations are further complicated by the fact that job loss to some extent correlates with noneconomic factors that influence both mobility and earnings, such as health and family formation decisions.

We will use the theories discussed above as guidance for our empirical strategy and when interpreting the results. We are interested in understanding better the motives for moving and how the decision-making process might differ between different types of workers. When we assess heterogeneity in the opportunity costs of moving in the first part of our analysis, we take into account gender, education level, age, family structure, spouses' employment, and the location of family members. When we assess the postdisplacement labor market experience of movers and stayers in the second part of our analysis, we exploit the richness of our data to better understand the decision-making process and how labor market outcomes can be interpreted. We expect labor market outcomes to differ among workers who move for different reasons, and we therefore split the sample by gender and postmove location characteristics, such as urban status and the existence of family members. We also explore how job loss and migration interact with fertility, marital status, and disability.

\section{Data and Variable Definitions}

Our primary data set is linked employer-employee data that cover all Norwegian residents between the ages of 16 and 74 years in 1986-2008. It combines information from various administrative registers, such as the 
education register, the family register, the tax and earnings register, and the social security register. A unique person identification code allows us to follow workers over time. Unique spouse (i.e., married or cohabiting partner) codes also exist and allow us to analyze the outcomes of spouses over time. Likewise, unique firm and plant codes allow us to identify each worker's employer and to examine whether plants are downsizing or closing down. We also have a code for the individual's municipality of residence and the corresponding local labor market region at the end of the year. This allows us to analyze mobility and to add information on local labor markets. ${ }^{13}$

Employment is measured as months of full-time equivalent employment over the year. ${ }^{14}$ Earnings are measured as annual taxable labor income. The included components are regular labor income, income as self-employed, and benefits received while on sick leave, being unemployed, or on parental leave. ${ }^{15} \mathrm{We}$ also use an alternative variable, income, which is earnings plus annual disability pension. This is done to capture the income of workers who leave the labor force. A third measure, family income, is defined as the sum of income for the worker and the spouse. Income and earnings are deflated to the 1998 Norwegian krone using the national consumer price index. Regionally adjusted real income is annual income deflated by a regional price index. This index is primarily based on house price differences across labor market regions and allows us to account for differences in living expenses. Tenure is measured in years, using the start date of the employment in a given plant. Education is measured as the normalized length of the highest attained education and is obtained from the education register. Educational attainment is split into three groups: primary, secondary, and tertiary education. The number of children and the children's age are obtained from the national registration office. Urban status is defined as living in one of the five largest labor market regions in Norway. Almost half of the population in Norway live in these urban regions. We calculate local unemployment rates using the individual level of months of unemployment variable. The unemployment rate is the sum of all unemployment months in the region divided by the sum of all employment and unemployment months in the region.

${ }^{13}$ Local labor markets span more than one municipality (the lowest administrative level) but are typically smaller than counties (the medium administrative level). There are 435 municipalities and 46 local labor market regions in Norway. During the years 1991-2001, the average population is 7,226 in the municipalities and 68,527 in the local labor markets. The average size of the urban locations is about 350,000 , while the average size of the rural locations is 35,000 .

${ }^{14}$ We have three intervals for working hours and use these to control for part-time employment as follows: $Y_{i t b}=0.1 \times$ months of employment if a worker is working less than 20 hours per week, $Y_{i t}=0.5 \times$ months of employment if a worker is working 20-29 hours per week, and $Y_{i t b}=$ months of employment if a worker is working more than 30 hours per week.

${ }^{15}$ Note that social assistance and student grants are not included. 
To examine the importance of family ties for mobility, we define variables describing the location of parents and siblings. An indicator variable Parents and sibling living in the labor market region means that a worker has a parent or sibling in the same regional labor market in the year of the observation. Since it is well established that firstborns are more mobile than younger siblings (Konrad et al. 2002), we also define a variable Younger siblings, meaning that a worker has at least one younger sibling.

\section{Sample Construction and Empirical Strategy}

We include all sectors in the Norwegian economy and study displacements taking place during the years 1991-2001. We label these years "base years." We construct separate samples for each base year by including observations of each worker 5 years prior to the base year and 7 years after. In the analyses, we pool the 11 base year samples to a panel spanning the years 1986-2008. This implies that the cross-sectional dimension in the panel is person $\times$ base year.

By tracing workers 7 years after the displacement incident, we can account for unemployed workers, workers temporarily outside the labor force (e.g., in education or on parental leave), and individuals who transfer to permanent disability pension. The latter is important because a large group of displaced workers leave the labor force permanently after job loss (Rege et al. 2009; Huttunen et al. 2011). Our upper age restriction is chosen so that no workers included in the sample qualify for regular early-pension schemes.

In line with earlier studies, displaced workers are understood to be individuals who involuntarily separate from their jobs due to exogenous shocks. We consider a worker displaced from his or her job in base year $b$ if the worker is registered with a new or no plant code in year $b+1$ and the plant in year $b$ satisfies one of the following three criteria: (i) the plant has closed down between years $b$ and $b+1$; (ii) the plant has reduced its number of employees by at least $30 \%$ between years $b$ and $b+1$ and had at least 20 workers in year $b$; or (iii) the plant closes down the following year (i.e., between years $b+1$ and $b+2$ ). The matches between workers and plants are based on administrative information from the end of May in the years 1991-4 and the end of November in the years 1995-2001. This implies that the actual displacement could have taken place either in year $b$ or in year $b+1$, but it most likely took place in $b+1$ when the match is done in November. Displaced workers are our treatment group. We use as our control group all workers who were not displaced between years $b$ and $b+1$. Importantly, we allow workers in the control group to separate for reasons other than displacement, such as voluntary job changes and sickness.

To ensure that the treatment and control groups are as similar as possible, we include only high-attachment workers in the base year samples. This is operationalized as workers who are between 25 and 50 years old in the base 
year, who are attached to plants with at least 10 workers, who have at least 1 year of tenure, who have lived in their current labor market region for at least 1 year, who have worked at least 20 hours per week in all years $b-3$ to $b$, who have annual earnings above NOK 30,000 in all years $b-3$ to $b$, and who have not been displaced in the years $b-3$ to $b$.

We split our treatment and control group into movers and stayers. Movers are defined as workers who change their local labor market code between years $b$ and $b+2$. Local labor markets span several municipalities and are defined by Statistics Norway on the basis of commuting patterns (Bhuller 2009).

\section{A. Displacement and Regional Mobility}

We begin by estimating the effect of displacement and background factors on regional mobility separately for males and females using the specification

$$
M_{i b+2}=\delta D_{i b}+\left(\delta_{g} D_{i b} G_{i b}\right)+\beta X_{i b}+\gamma_{b}+\varepsilon_{i b},
$$

where $M_{i b+2}$ is a dummy indicating whether worker $i$ lives in a different region 2 years after the base year, $b ; D_{i b}$ is a dummy indicating whether worker $i$ was displaced between years $b$ and $b+1$; and $X_{i b}$ is a vector of observable predisplacement worker, plant, and labor market characteristics, measured in the base year if nothing else is stated. We include age; age squared; education (split into three categories); tenure; marital/cohabitation status; number of children; a dummy for children under age 7 (preschool age); earnings in years $b-3, b-4$, and $b-5$; months of employment in years $b-4$ and $b-5$; a dummy for being in education in years $b-4$ and $b-5$; years of residence in the predisplacement region; plant size; region size; regional unemployment rate; a dummy for having a spouse; a dummy for having a spouse who is employed; a dummy for having younger siblings; a dummy indicating whether the parents of the worker or the worker's spouse are living in the same predisplacement region; a dummy indicating whether a sibling of the worker or the worker's spouse is living in the same predisplacement region; a dummy for having both parents and siblings in the predisplacement region; base year two-digit NACE (Statistical Classification of Economic Activities in the European Community) industry dummies; and base year region dummies. The specification also includes base year fixed effects, $\gamma_{b}$.

The displacement dummy, $D_{i b}$, is the variable of main interest. The associated parameter $\delta$ gives the difference in regional mobility between displaced and nondisplaced workers conditional on the predisplacement controls. As the migration decision in families is determined by both spouses' employment status, we add an indicator for the other spouse's job displacement status in some specifications. To analyze heterogeneity in the moving propensity after job loss, we interact the displacement dummy with various group dum- 
mies defined by using predisplacement variables, such as education category, the earnings level in year $b-3$, predisplacement urban status, predisplacement family status (married or cohabiting), and a predisplacement family tie indicator (parent or spouse's parent living in the same predisplacement region). These dummy variables are contained in the vector $G_{i b}$.

\section{B. Income Losses after Displacement for Movers and Stayers}

To analyze how the earnings effects of job loss are related to moving decisions, we estimate the following model separately for males and females:

$$
Y_{i b t}=\sum_{j=-3}^{7} D_{i b t-j}^{\text {mover }} \delta_{j}^{\text {mover }}+\sum_{j=-3}^{7} D_{i b t-j}^{\text {stayer }} \text { stayer }_{j}^{\text {sto }}+\beta X_{i b t}+\gamma_{b t}+\alpha_{i b}+\varepsilon_{i b t} .
$$

In equation (2), $Y_{i b t}$ is annual earnings, annual income (including disability pension), or family income for worker $i$ in base year sample $b$ at time $t$, and $X_{i b t}$ is a vector of observable predisplacement characteristics from base year $b$ and current year age and age squared. The variables $D_{i b t-j}^{\text {mover }}$ and $D_{i b t-j}^{\text {stayer }}$ are the variables of main interest. These are dummy variables for displaced movers and stayers indicating whether a displacement occurred in year $t-j$, with $t$ being the observation year. The associated parameters $\delta_{j}^{\text {mover }}$ and $\delta_{j}^{\text {stayer }}$ measure the earnings or income differentials in pre- and postdisplacement years $j \in[-3, \ldots, 7]$ of displaced movers and displaced stayers relative to all nondisplaced workers.

The specification also includes base year-specific time dummies, $\gamma_{b t}$, to ensure that we compare earnings of displaced and nondisplaced workers in the same base year sample and with the same distance to the base year $(-3$ to 7). Finally, we also include base year-specific individual fixed effects, $\alpha_{i b}$, to control for permanent differences in earnings between displaced movers and displaced stayers and nondisplaced workers (in a given base year). When including worker base year fixed effects, we cannot include any timeinvariant base year controls. We cluster standard errors by individual $i$ to allow for correlation of the error terms, $\varepsilon_{i b t}$, across different time periods and base years for individual $i$. We also acknowledge that earnings growth may differ between workers with different observational characteristics. Glaeser and Mare (2001) find, for example, that the earnings growth of highly educated workers and workers in urban areas differs from the earnings growth of less educated workers and workers in rural areas. To take such effects into account, we let the age-earnings profiles differ between workers in urban and rural locations and between workers in different educational categories. Specifically, we interact age and age squared in the regression with base year urban status and education categories (primary, secondary, and tertiary). These interaction terms are added to $X_{i b t}$.

At the end, we undertake a more descriptive regression analysis where we investigate whether workers who move to a region where they have parents 
(back home) have different labor market outcomes than those who most likely move for work-related reasons. In addition, we analyze whether moving to rural and urban areas makes a difference in terms of earnings. The reason for this descriptive exercise is that quite a few displaced workers move back to where they originally came from. There may be many reasons for this, such as cheaper housing, wanting to live closer to one's parents, or wanting to go back to where one grew up.

\section{Family and Health Outcomes}

To better understand the motives for moving and to better interpret the outcomes, we analyze whether job loss and mobility decisions are associated with changes in workers' decisions to stay married, decisions to form a family, and health status. We estimate the following linear probability model separately for each time period $(t)$ :

$$
F_{i b t}=\lambda_{j}^{\text {mover }} D_{i b t-j}^{\text {mover }}+\lambda_{j}^{\text {stayer }} D_{i b t-j}^{\text {stayer }}+\beta X_{i b t}+\gamma_{b t}+\varepsilon_{i b t},
$$

where $F_{i b t}$ is an indicator for whether worker $i$ in base year sample $b$ at time $t$ divorces the base year spouse, gets married or enters into cohabitation, gives birth, or receives a disability pension and $X_{i b t}$ contains current year age dummies and observable predisplacement characteristics. As before, the variables $D_{i b t-j}^{\text {mover }}$ and $D_{i b t-j}^{\text {stayer }}$ are dummy variables for displaced movers and displaced stayers indicating whether a displacement occurred in year $t-j$. The associated parameters $\lambda_{j}^{\text {mover }}$ and $\lambda_{j}^{\text {stayer }}$ measure the outcome differentials in pre- and postdisplacement years $j \in[-3, \ldots, 7]$ of displaced movers and displaced stayers relative to all nondisplaced workers.

\section{Job Displacement and the Mobility Decision}

Job loss represents a shock to income, and theory suggests that this will increase the likelihood of migration by reducing the opportunity cost of moving. Figure 1 describes the share of movers among displaced and nondisplaced workers up to 7 years following displacement (out-migration from the base year region) and 5 years prior to displacement (in-migration to the base year region). As expected, we see that displaced workers of both genders have a higher probability of moving than nondisplaced workers. ${ }^{16}$ The share of displaced males who move to a new region by the second year

${ }^{16}$ The figure also shows that mobility in Norway is high. Without restricting our data to prime-age full-time workers, the annual mobility rate across regional labor markets is almost $3 \%$, and the mobility rate across municipalities is $4 \%-5 \%$. These numbers are slightly lower than in the United States and are in line with previous research that rank Norway and other northern European countries on top with respect to regional mobility rates in Europe. See Molloy, Smith, and Wozniak (2011) and Machin, Pelkonen, and Salvanes (2012). 


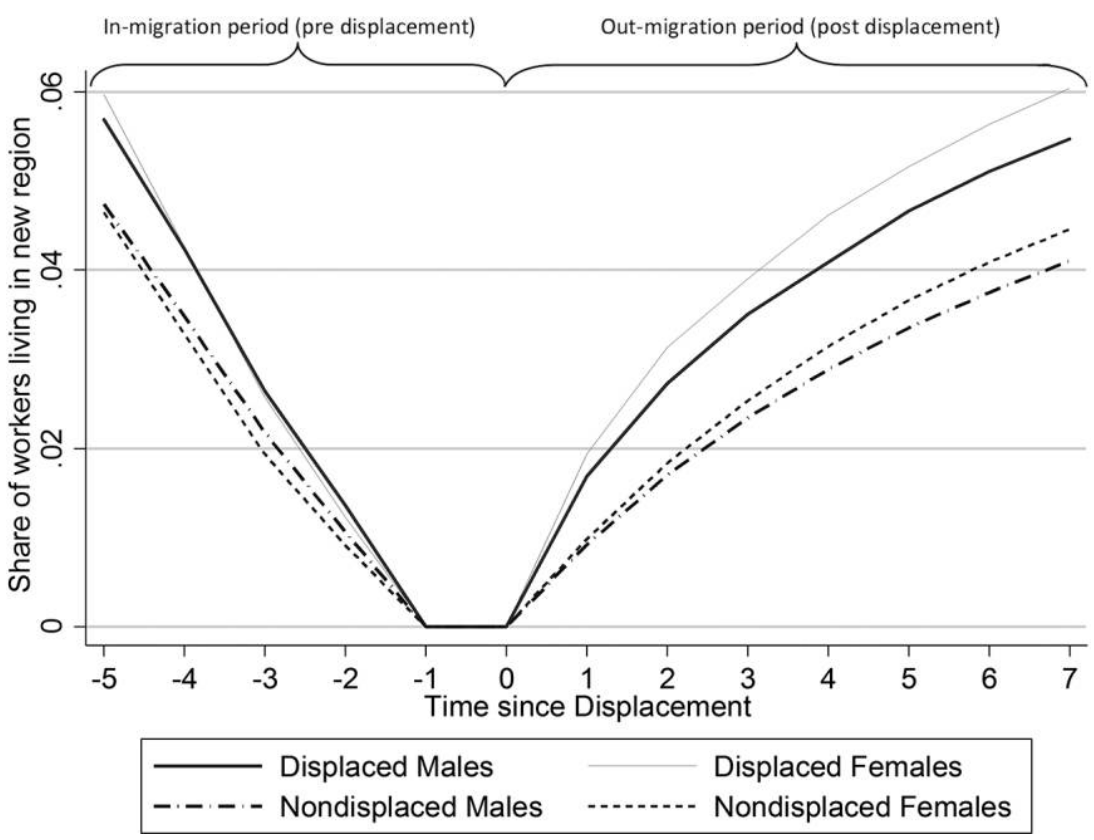

FIG. 1.- Share of workers living in a different region than in the base year. Moving is defined as living in a different labor market region than in the base year (year 0). Displacement happens between year 0 and year 1 . The sample consists of prime-age workers with high labor market attachment (see Sec. IV). Staying in the same labor market in both year 0 and year -1 is part of the sample criteria.

after job loss is $2.7 \%$, while the share of nondisplaced males who move is $1.7 \%$. The share of displaced females who move is $3.1 \%$, while the share of nondisplaced females who move is $1.8 \%$. Hence, there is a 1.0-1.3 percentage point difference for displaced compared with nondisplaced workers. This indicates an unconditional increase in the probability of moving after being displaced of about $60 \%$. Note, however, that this is from a relatively low level of around 2\%. From the second year onward, the difference does not increase very much, so it seems to be the first shock of displacement that drives the migration decision.

With respect to in-migration, the first thing to notice is that the overall share of migrants is somewhat higher 5 years before displacement than 5 years after displacement. This is most likely a general age effect. As explained in the theory section, the likelihood of migration decreases with age. Another noticeable feature of figure 1 is that future displaced workers have a somewhat higher in-migration probability than future nondisplaced workers. Although the predisplacement difference is much smaller than the postdisplacement difference, this suggests that our effort to sample workers who are strongly attached to the labor market is not enough to make the treat- 
ment and control groups perfectly comparable. It is a common finding in the displacement literature that displaced workers have slightly different characteristics than nondisplaced workers. In table A1 (tables A1-A6 are available online), we make a more in-depth comparison of displaced and nondisplaced workers in our sample. The numbers suggest that the higher in-migration rate is due to the fact that workers with short tenure are overrepresented among those who become displaced. The workers in the displaced group have about 1 year shorter tenure on average. Along all other dimensions, the two groups are close to identical. We account for the observed difference by including several predisplacement characteristics as control variables in our regression analyses. ${ }^{17}$

\section{A. Regression Results: The Determinants of Mobility}

We analyze mobility using the specification given in equation (1) and report marginal probit effects in table 1. The dependent variable is a dummy for whether the worker moves to a different labor market region within 2 years after job loss. Results for men are reported in panel A, and results for women are reported in panel B. On the basis of our theoretical framework, we expect a worker's mobility decision after job loss to depend on education, spouses' employment situations, local economic conditions, and location-specific amenities, such as family ties.

From column 1 we see that displacement increases the probability of moving by $0.5-0.6$ percentage points, all else equal. This is a small overall increase but represents about a $30 \%$ increase in the moving propensity, since the mean probability of moving to a new region by year 2 is $1.7 \%-1.8 \%$ for nondisplaced workers. The coefficients on our control variables are as expected. To avoid a very lengthy table they are not reported, but we find, for example, that college-educated workers have a much higher probability of moving than others, that a high local unemployment rate increases the probability of moving, and that having a spouse who is employed, having school-age children, and having parents in the region all reduce the probability of moving (see table A5).

In columns 2-7 we analyze selection on observables into mobility by including interaction terms between displacement and important observable predisplacement characteristics. Concentrating on men, the first thing to

${ }^{17}$ As a robustness exercise we have also used a formal prescreening procedure to trim the sample. In this case, we first estimated the probability of displacement based on a rich set of predisplacement characteristics from years $t-5$ to $t$ (see table A4). Next, we dropped observations with a predicted propensity for treatment below 0.05 and above 0.95, following Crump et al. (2009). With this sample procedure, the predisplacement observable differences clearly diminish, as can be seen in table A3 and fig. A10. Main results based on the prescreened sample are reported in figs. A11 and A12. These figures are very similar to the corresponding figs. 3 and 7 in the main text. 


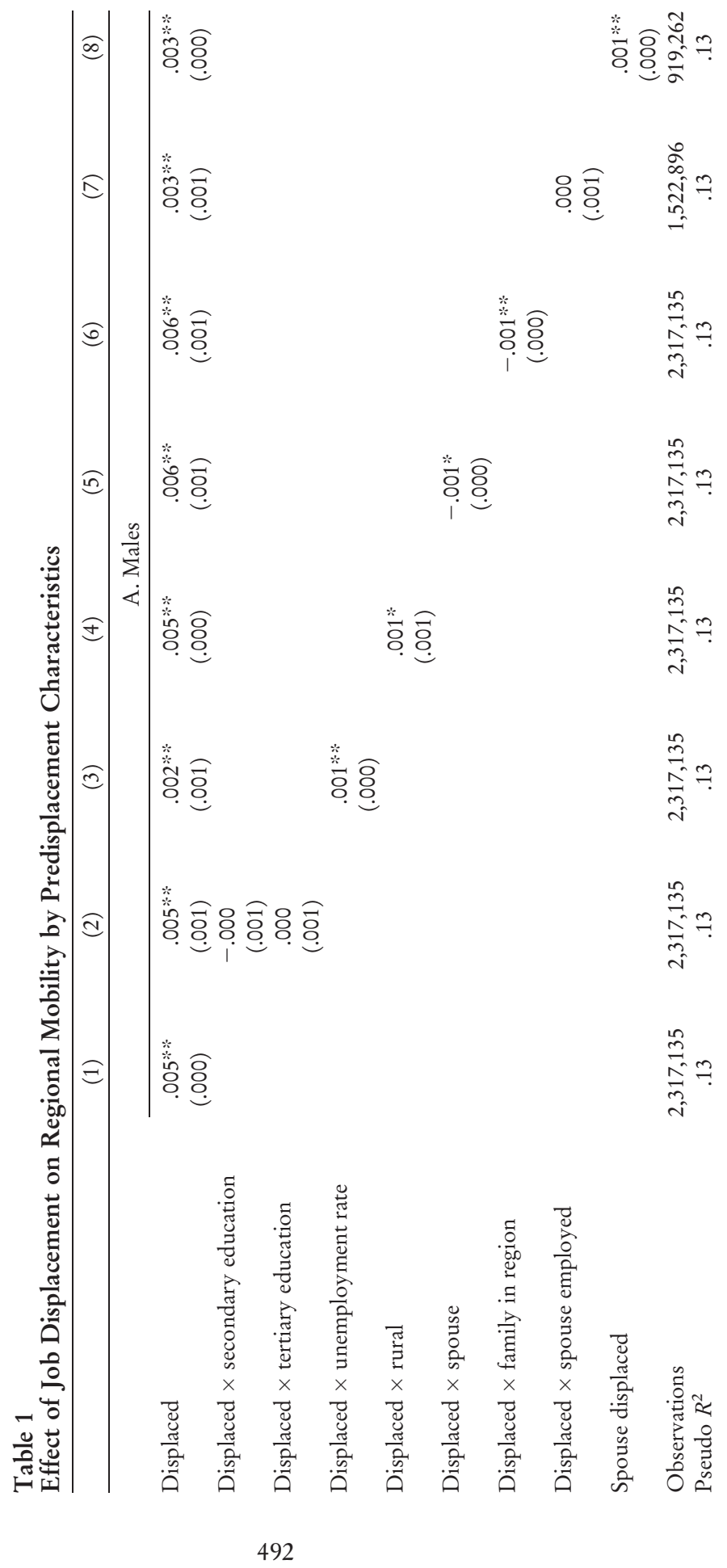

This content downloaded from 130.233.216.094 on May 04, 2018 01:26:34 AM 


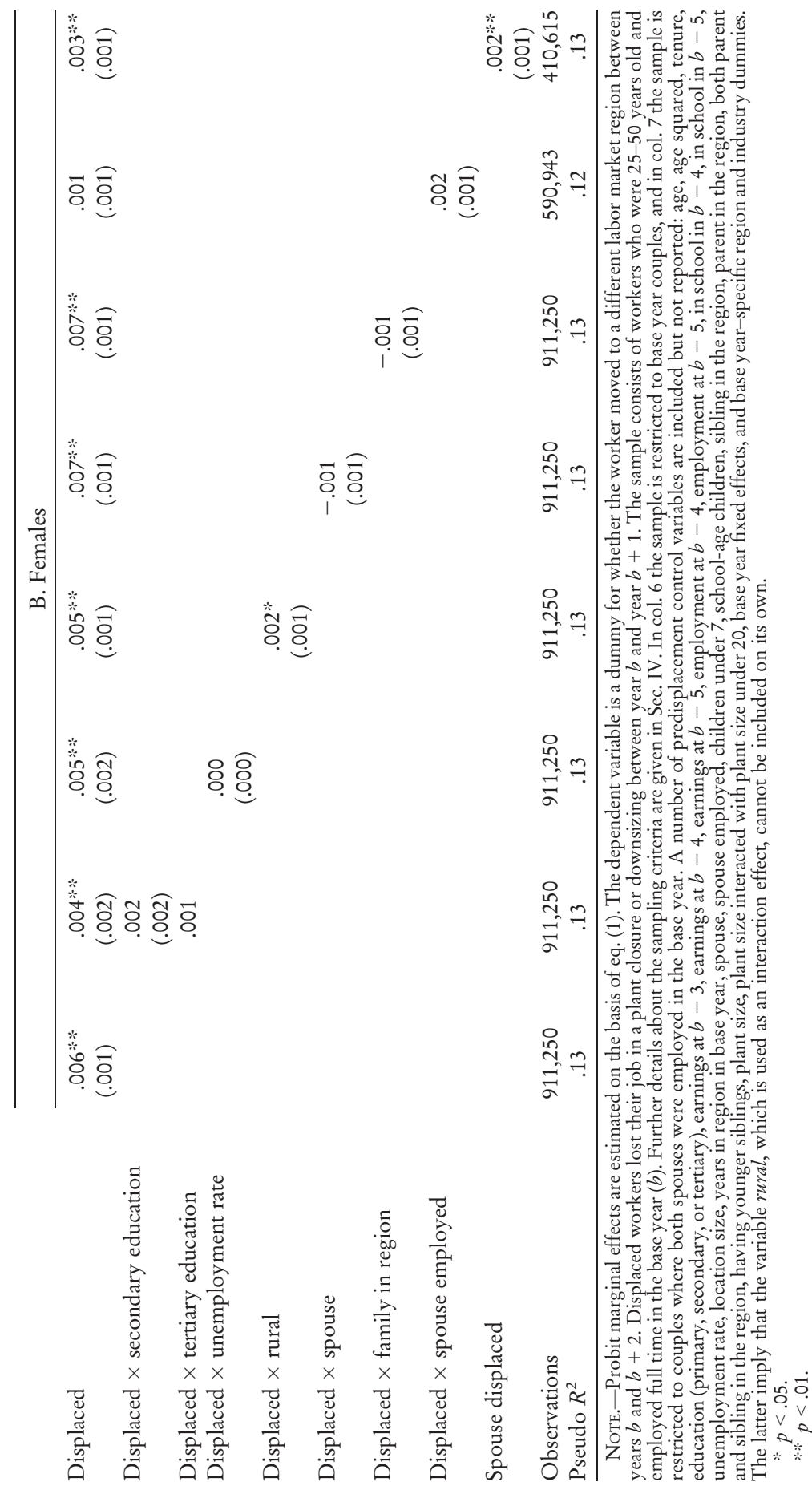

493

This content downloaded from 130.233.216.094 on May 04, 2018 01:26:34 AM 
notice is that higher education does not seem to increase the moving propensity more for displaced workers than for nondisplaced workers. In line with theory, however, we find that a high local unemployment rate increases the moving propensity for displaced workers more than for nondisplaced workers. Likewise, living in a rural location increases the moving propensity after job loss. With respect to family variables, we find that displaced workers with a spouse have lower moving propensity and that those who have family members in the region also are less likely to move after job loss. To investigate how spouses' employment matters for mobility, we restrict the sample to couples in the last two columns. In column 6 we analyze the importance of whether the spouse is employed, and in column 7 we analyze the importance of whether the spouse is also displaced. We find that having an employed spouse does not reduce mobility more for displaced workers than for nondisplaced workers but that having a spouse who is also displaced increases the moving propensity. Note from panel B that this effect is twice as large for women having their husband displaced as it is for men having their wife displaced. None of the other estimated interaction terms differ much between displaced men and displaced women, but only the effect of living in a rural area is significant for women.

\section{Labor Market Outcomes for Movers and Nonmovers}

Having established that displacement affects the propensity to move, we now investigate how those who move after displacement succeed in the labor market compared with displaced workers who stay and with nondisplaced workers. We acknowledge that this analysis is descriptive, as the decision to move is endogenous, but we conduct the analysis within a fixed effects framework.

As discussed in Section II, the motive for moving will differ among workers. Some workers move to improve their labor market outcomes, while others move for non-work-related reasons, typically family-related reasons. The former group may consist of both positively selected workers (those who move because they obtain a better wage offer in a different location) and negatively selected workers (those who move because they cannot find a new job in their current location). Hence, movers may be a very heterogeneous group. They will differ in terms of preferences, how severely they are affected, and with respect to life events that may be correlated with job loss.

\section{A. Earnings and Income after Job Loss by Moving Status}

In figure 2 we present mean annual earnings and regionally adjusted income by moving and displacement status. Workers are included in the sample even if they have zero annual earnings. This implies that we capture the joint effect of changes in employment and wage rates. In the regression analyses to follow, we will compare displaced movers to displaced stayers and then compare both groups to a control group of all nondisplaced workers. It 


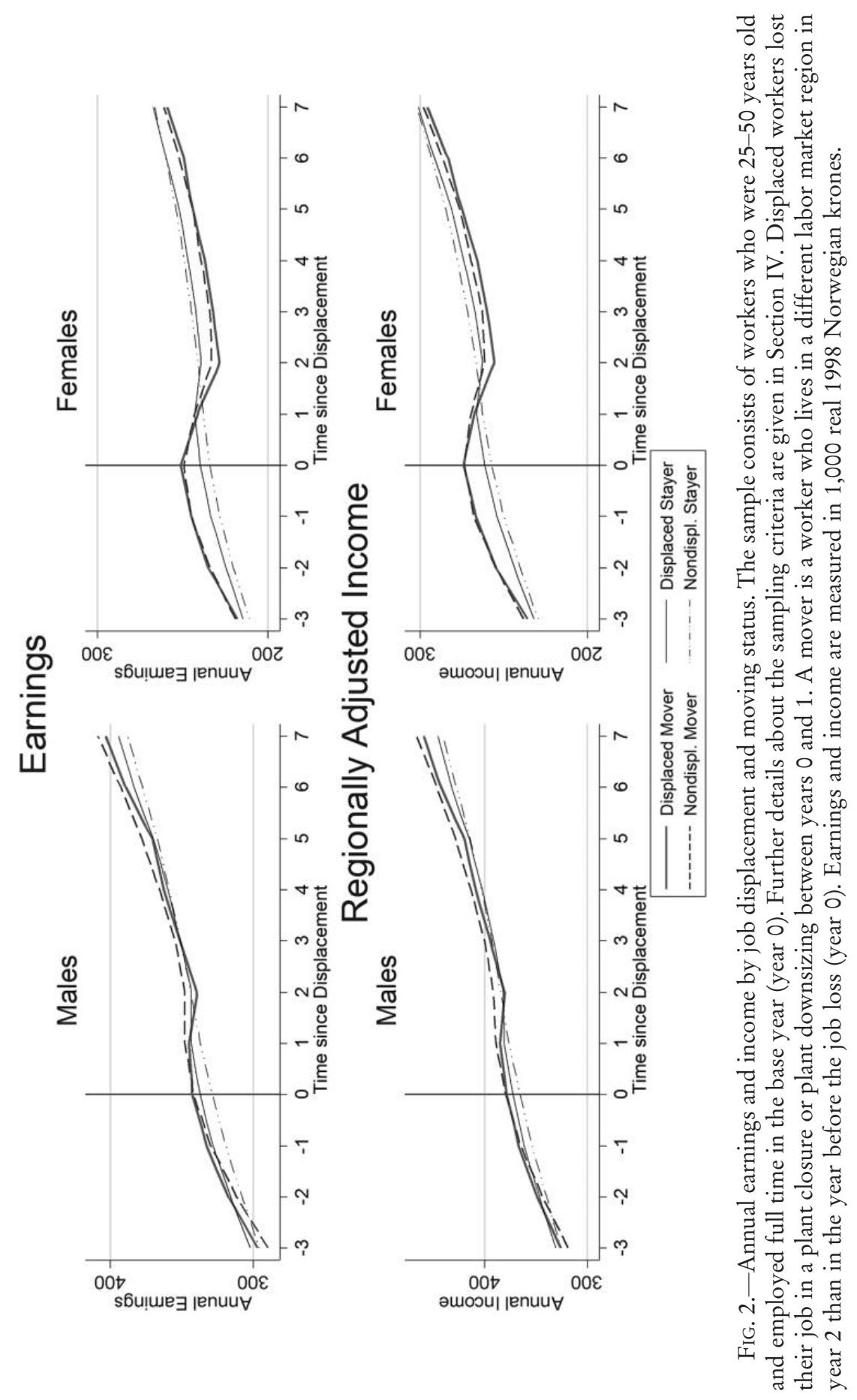

This content downloaded from 130.233.216.094 on May 04, 2018 01:26:34 AM 
is therefore of particular interest to assess whether the various groups have similar predisplacement trends.

We see that the predisplacement earnings differences between displaced and nondisplaced workers are relatively small and that the differences are mostly level effects. Note also that the difference between movers and stayers is more evident than the difference between displaced and nondisplaced workers. In both groups, movers have on average higher predisplacement earnings than stayers in year 0 , suggesting that movers are on average positively selected on observables. Changing the outcome variable from earnings to regionally adjusted income (including disability pensions) in the lower part of the figure gives very similar results, but it seems to make the loss for displaced movers slightly smaller.

The graphs in figure 2 show that job loss opens up an earnings gap between displaced and nondisplaced workers. This is in line with the previous literature. The largest earnings drop in the figure is observed for female movers, but the difference between displaced and nondisplaced female movers is small. More interesting - and perhaps puzzling - is the finding that displaced movers seem to have a larger earnings drop than displaced stayers even though movers at the outset appear to be positively selected. This underlines the fact that displaced workers move partly for non-workrelated reasons so that the estimated effect is a mix of causation and selection. As explained in the theory section, there may be personal latent motives for relocation so that a reduction in opportunity costs caused by job loss triggers a migration decision that is not primarily driven by earnings. We will investigate alternative explanations in more detail below, using regression and by splitting the sample. We will start by comparing ordinary least squares (OLS) results to a simple person fixed effects framework in order to account for selection driven by talent.

\section{B. Main Regression Results}

Our main earnings regression is specified is equation (2), and the estimated earnings profiles for stayers and movers are visualized in the top row of figure 3. What we have plotted is the fixed effects point estimates and confidence intervals for the job displacement dummies. ${ }^{18}$ We see long-lasting earnings reductions for movers as well as for stayers, but the loss is significantly larger for movers than for stayers. ${ }^{19}$ This again suggests that the mobility decision is driven by reasons other than economic gains.

18 Tabulated regression results are included in table A6. A more detailed discussion of the results can also be found in the appendix.

${ }^{19}$ A priori, one might expect the earnings loss to be largest in year 1, but since displacement happens between years 0 and 1 , many displaced workers are nondisplaced in parts of year 1 . Moreover, severance pay and termination payment agreements are commonly used when firms downsize. This will typically be paid out in year 1 or year 2 and can be on the order of one month's pay per year of service. 


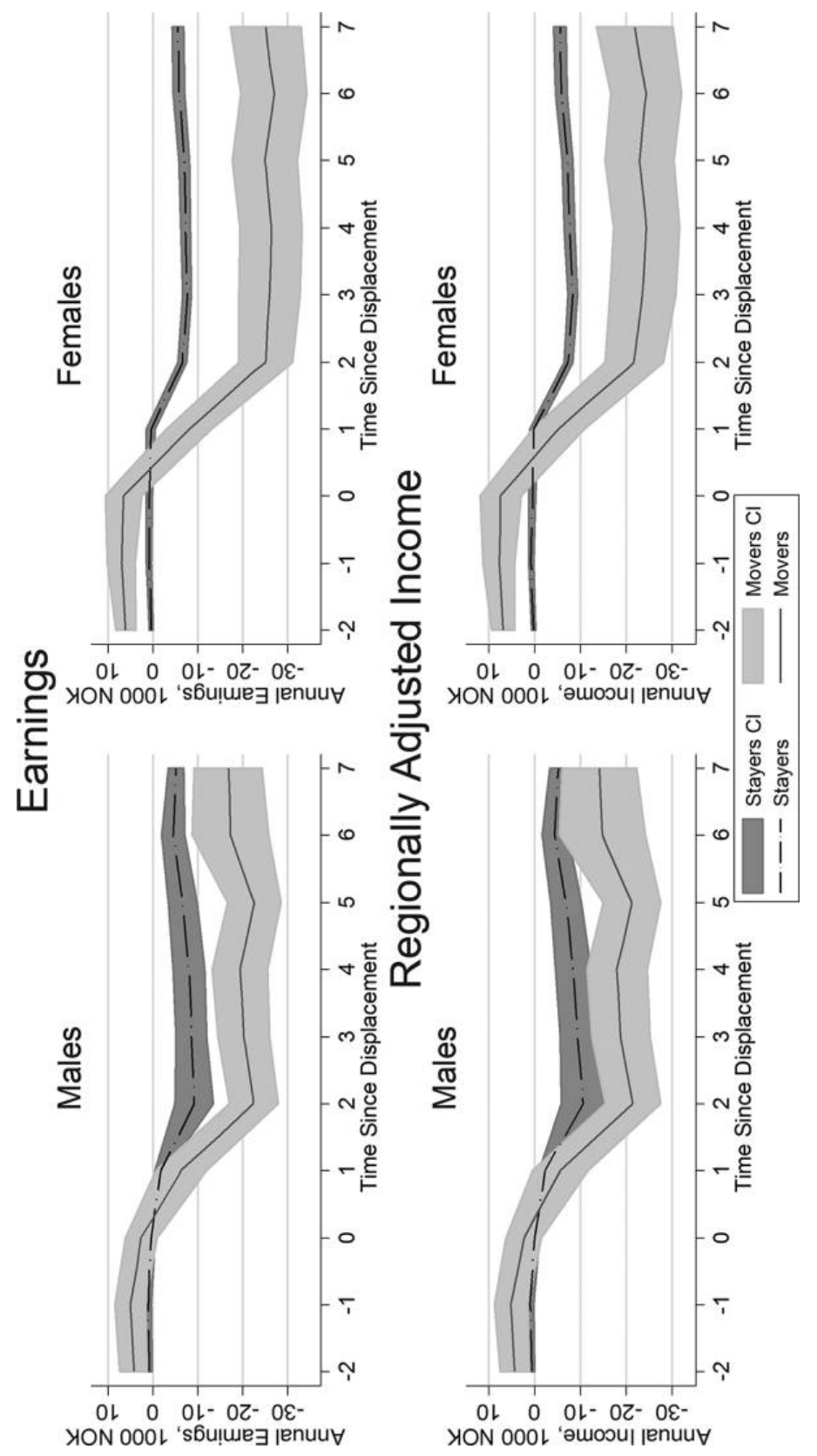

चี

홍 준

$\left({ }_{0}^{\circ} \circ\right.$

0 표

品

क्ष

可

4 .

n.

물

च

.

6.

氙总

:

悹兽

के

舟

․․ㅍㄷ

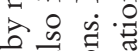

๘

可

कै एँ की

ठृ

픙

के

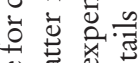

당

氙.

就

娄

ज.

항

สี

চ大.

ज्ञ हैं

त् 0

की

हु

ㄷ․․․․․․

(1)

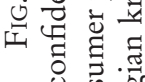


The average annual earnings decrease for displaced male movers in the second postdisplacement year is NOK 22,400 (about 4,000 current US dollars). ${ }^{20}$ This corresponds to $-6.2 \%$ compared with their counterfactual earnings. ${ }^{21}$ For displaced male stayers, the average decrease in the second postdisplacement year is NOK 9,200 (about 1,650 current US dollars). This corresponds to $-2.6 \%$ of their counterfactual earnings. From figure 3 we also see that the earnings loss associated with job displacement is very long-lasting. In year 7 the estimated earnings loss is still $4.0 \%$ for displaced movers and $1.3 \%$ for displaced stayers. ${ }^{22}$

For women, the difference in the earnings loss between stayers and movers is even more pronounced. In the second postdisplacement year, the earnings drop for displaced female movers is on average NOK 25,300. Since average female earnings are lower than male average earnings, this corresponds to $-10.0 \%$ of counterfactual earnings. For displaced female workers who stay in the predisplacement region, the estimated loss is NOK 6,400 , corresponding to $-2.6 \%$.

The difference between movers and stayers may partly reflect the fact that some workers move to regions with lower costs of living. To take this into account, we have run the same regressions using a regionally adjusted income measure as the dependent variable. These results are reported in the bottom row of figure 3. Again, we find that movers have larger income losses after job displacement than stayers. The short-term magnitude is about the same as for earnings, but the difference between movers and stayers diminishes somewhat more over time.

\section{Family Income after Job Loss by Moving Status}

The results so far indicate that the earnings losses after job loss differ between movers and stayers, especially among females. Since Mincer (1978), it has been well established that it is the net family gain rather than the net personal gain that motivates migration. To take this into account, we also estimate the effect of displacement and mobility on total family income for a sample of workers who had a spouse in the base year. Total family income

${ }^{20}$ Our earnings measure is the real 1998 Norwegian krone. Changing this to the 2016 Norwegian krone implies multiplying by a factor of 1.45 . The current exchange rate is NOK 8.1 per US dollar.

${ }^{21}$ Following Davis and von Wachter (2011), the counterfactual earnings in the absence of job displacement are constructed by adding the absolute value of the estimated earnings loss to the mean earnings of the group in the period.

22 The estimated annual earnings loss after displacement is relatively small compared with estimates for the United States and other countries. Davis and von Wachter (2011) found that in recovery periods earnings losses in the United States are around $23 \%$ immediately after displacement and 10\% 7 years after. In recessions, the losses are even larger. Estimates for Germany by Schmieder et al. (2009) 
is the sum of a worker's own annual real income and the annual real income of the spouse. The regression results with total family income as the dependent variable are presented in the bottom row of figure 4. For comparison, own income results are presented in the top row.

For displaced males with a spouse in the base year, there is a reduction in own income and family income after job loss. As before, movers have larger losses than stayers in the years immediately following job loss. The family income loss in year 2 for displaced male movers who have a spouse in the base year is $\mathrm{NOK} 40,300(-7.0 \%)$, and for similar displaced male stayers it is $\mathrm{NOK} 8,900(-1.6 \%)$. For displaced female movers who have a spouse in the base year, the drop in year 2 family income is $\operatorname{NOK} 57,700(-9.7 \%)$, and for similar female stayers it is $\mathrm{NOK} 9,600(-1.7 \%)$. The difference in family income loss between movers and stayers appears to be permanent. Hence, optimization over family income does not explain why movers experience lower postdisplacement earnings than stayers. ${ }^{23}$

To further understand why there seems to be a negative effect of mobility on own income, even conditional on worker fixed effects, we will focus on two more issues. First, we assess worker heterogeneity in the opportunity costs of moving by splitting the sample by moving motives, such as family network amenities, and whether one is moving to an urban or a rural labor market. Second, since migration can be affected by life events that may correlate with job loss, such as health, fertility, and family formation decisions, we will explicitly look at how such outcomes interact with the mobility decision after job loss.

\section{To What Extent Does the Earnings Loss Depend on Where You Move To?}

Figure 5 shows that displaced workers who move to urban regions do not suffer any significant postdisplacement earnings losses at all. The earnings loss associated with job displacement for movers is entirely driven by individuals

and for Finland by Huttunen and Kellokumpu (2016) also indicate short-term losses around $20 \%$ and long-term losses around $10 \%$. Both of these studies focus on job displacement during deep recessions, however. We analyze a long and quite stable period with relatively low unemployment (see fig. A3). In addition, workers in Norway have generous social insurance in the form of unemployment and welfare benefits.

${ }^{23}$ As an extension to our family analyses we have also looked at the earnings effect of having a spouse that experiences job loss. The results are reported in fig. A4. Interestingly, we find that for movers the short-term effect of having a spouse who loses his or her job is as large as the effect of own job loss, but the long-term effects are smaller. Comparing males and females, we find that the effect on own income of spousal job loss is somewhat larger for females than for males, while the effect on family income of spousal job loss is smaller for females than for males. 


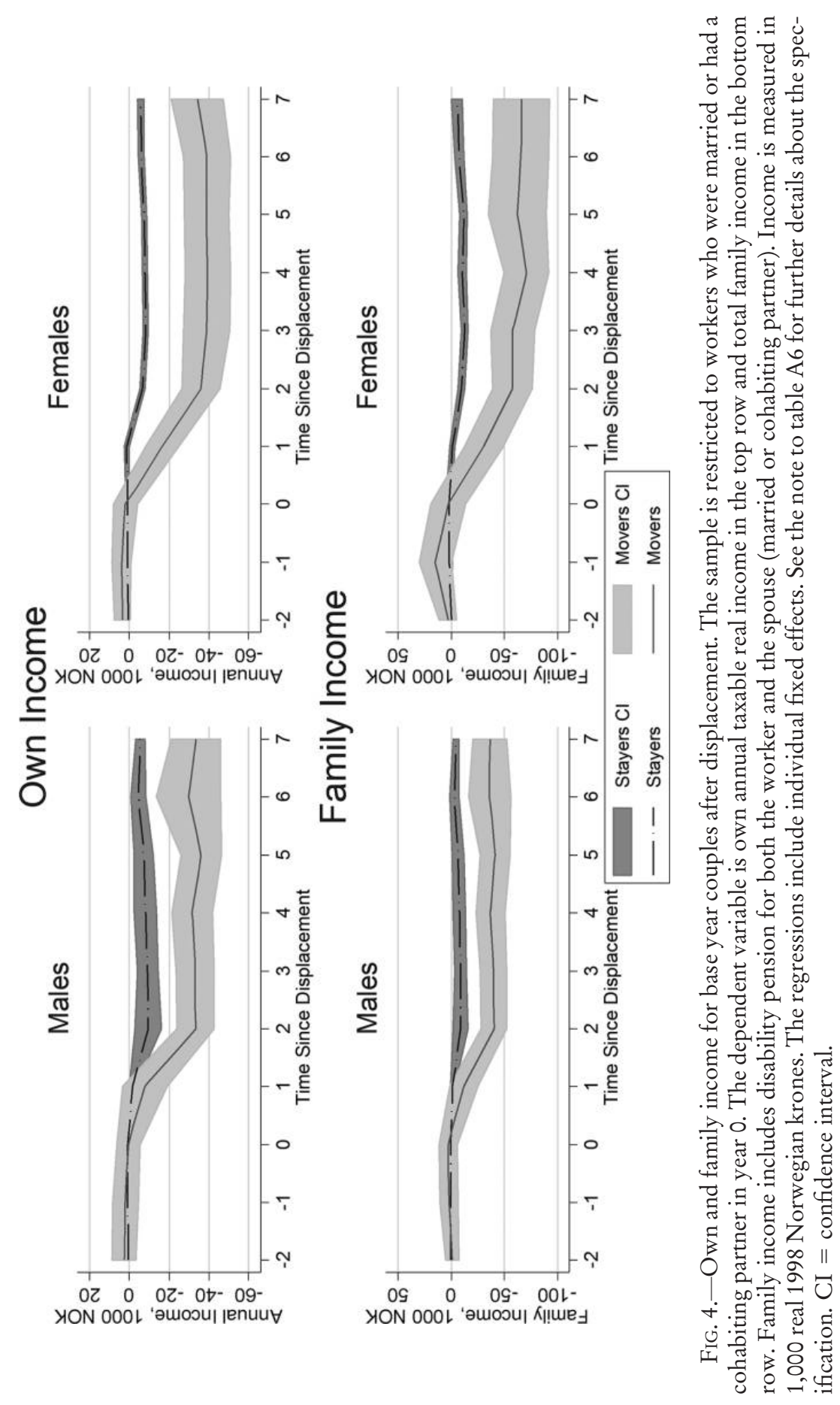




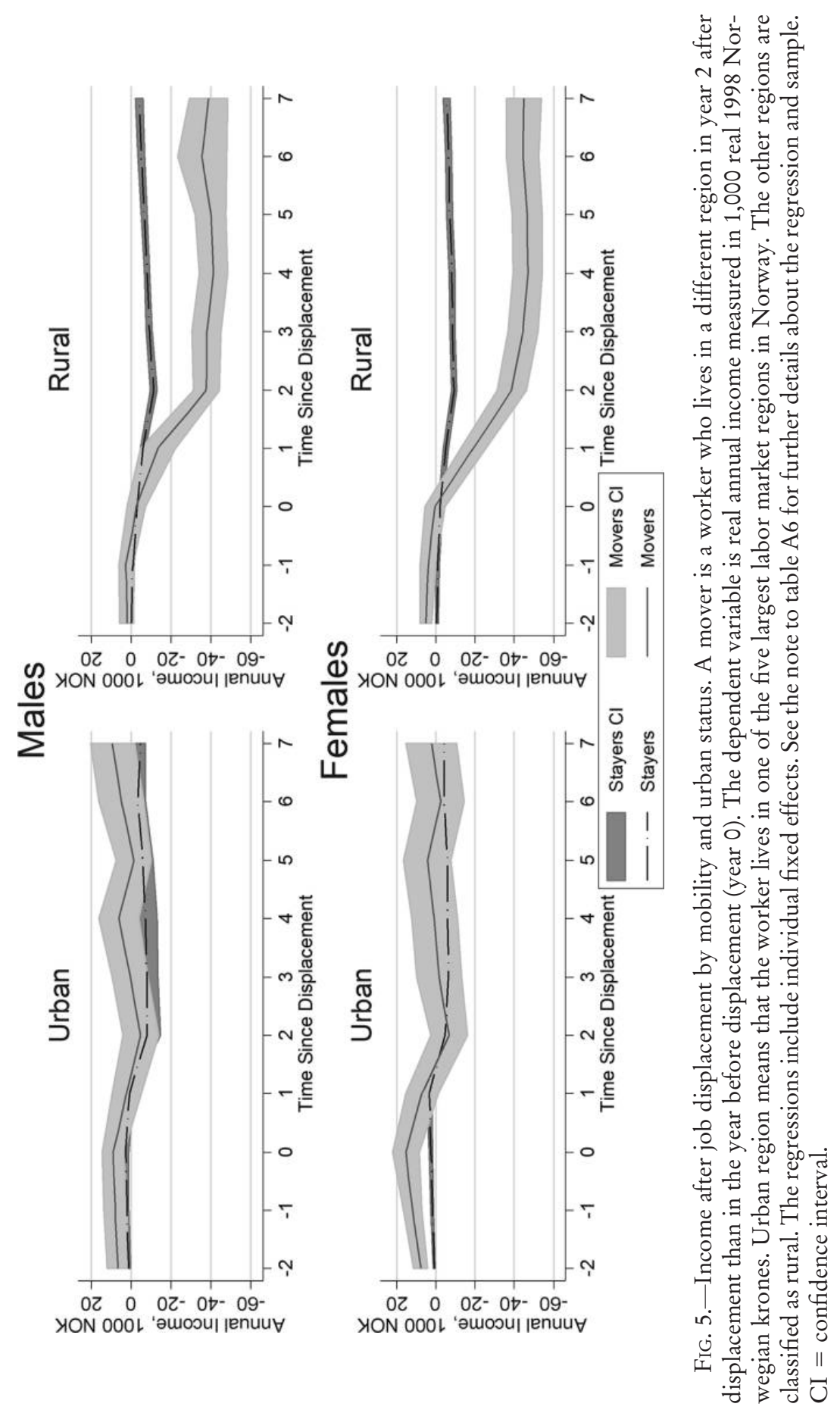


who move to rural locations. ${ }^{24}$ Stayers, both urban and rural, also suffer income losses after displacement, but the drop is very modest. ${ }^{25}$ We have further investigated how the postdisplacement earnings losses differ depending on whether one is moving from an urban or a rural location. Not surprisingly, these results indicate that movers from urban to rural locations suffer the biggest earnings losses (reported in fig. A6; figs. A1-A12 are available online). It is also interesting to note that rural to urban displaced movers realize a significant long-term increase in earnings and that rural to rural movers do significantly worse in the short run than rural stayers.

Figure 6 shows that workers who move to a region where they or their spouse have parents suffer bigger earnings losses than workers who move to regions where they do not have family. Interestingly, those who stay in regions where they have family seem to suffer the smallest earnings losses. This suggests that family networks play an important role in finding a new job. Otherwise, one would think that the higher opportunity cost of moving should make this group accept lower wage offers than, for example, workers who move to a region where they do not have family or workers staying in a region where they do not have family. ${ }^{26}$

\section{E. Fertility and Family Formation Decisions around Moving and Job Loss}

As discussed in Section II, several studies have documented that job loss affects health, the decision to stay married, and the decision to have children. We will now analyze how such outcomes interact with the mobility decision after job loss. Although health and personal life events may affect the decision to move, the following labor market outcomes can obviously not be seen as causal effects of moving after job loss.

In figure 7 we show coefficients from OLS regressions that estimate the effect of being a displaced mover and a displaced stayer on the probability of

${ }^{24}$ Urban is defined as living in one of the five largest labor market regions, as described in Sec. III. About $60 \%$ of the displaced stayers live in an urban region in year $b+2$, and about $50 \%$ of the displaced movers live in an urban region in year $b+2$. We have also experimented with using the three and the seven largest labor market regions. The results remain qualitatively similar (see fig. A7 for earnings results and table A5 for probability of migration results).

${ }^{25}$ Using employment as the dependent variable, we also find bigger employment losses for displaced workers moving to rural regions than for those moving to urban regions. With respect to employment, however, there is a difference between those who move to an urban region and those who stay in an urban region after displacement. The former group is less employed (see fig. A5).

${ }^{26}$ Further analyses are available in the appendix. Figure A8 shows effects on employment, and fig. A9 investigates how the earnings losses differ depending on whether the workers are moving from a region where they have family or from a region where they do not have family. We see that workers who move back to a region where they have family from a region without any family members have the biggest earnings losses. 


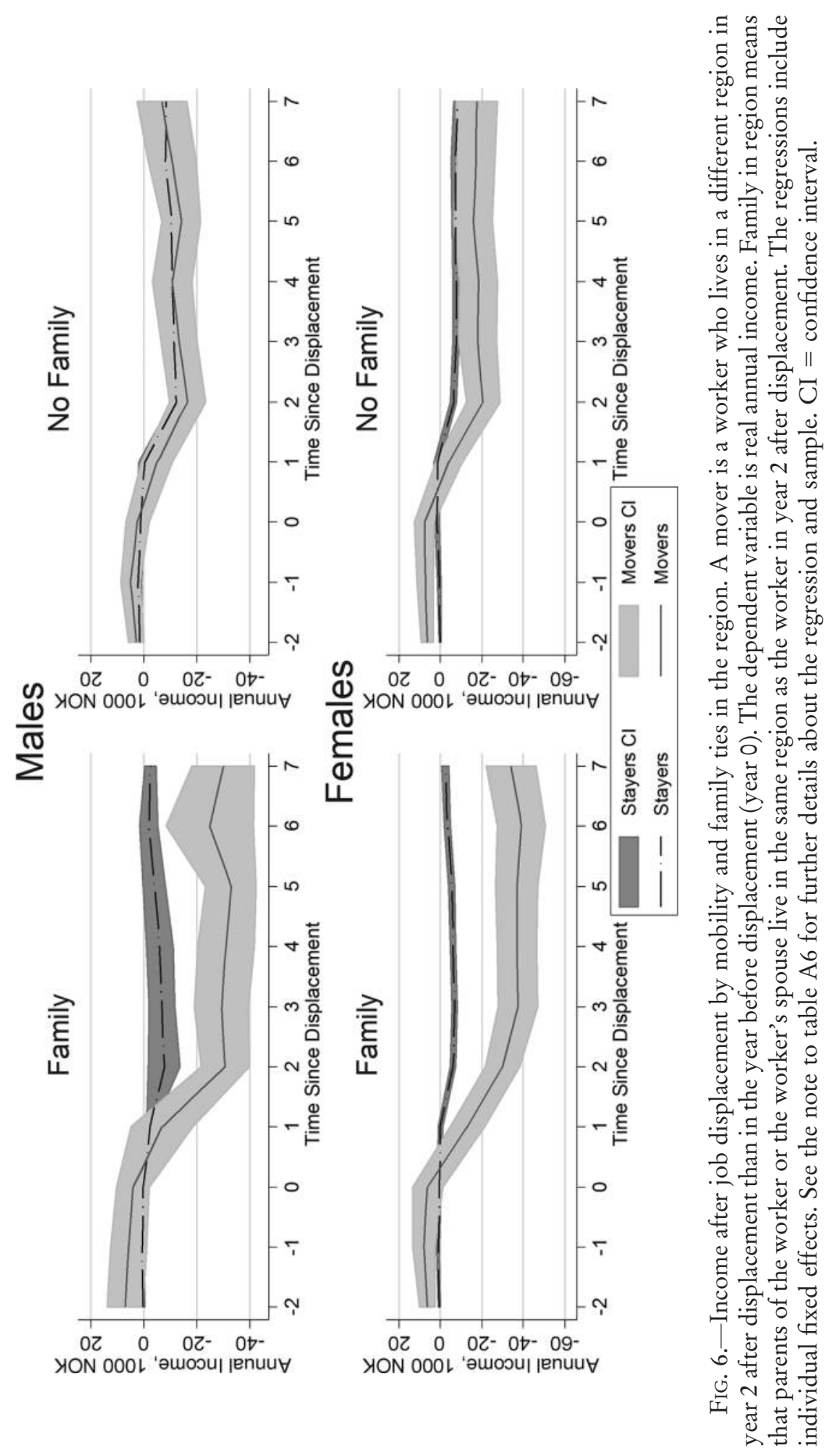

This content downloaded from 130.233.216.094 on May 04, 2018 01:26:34 AM 


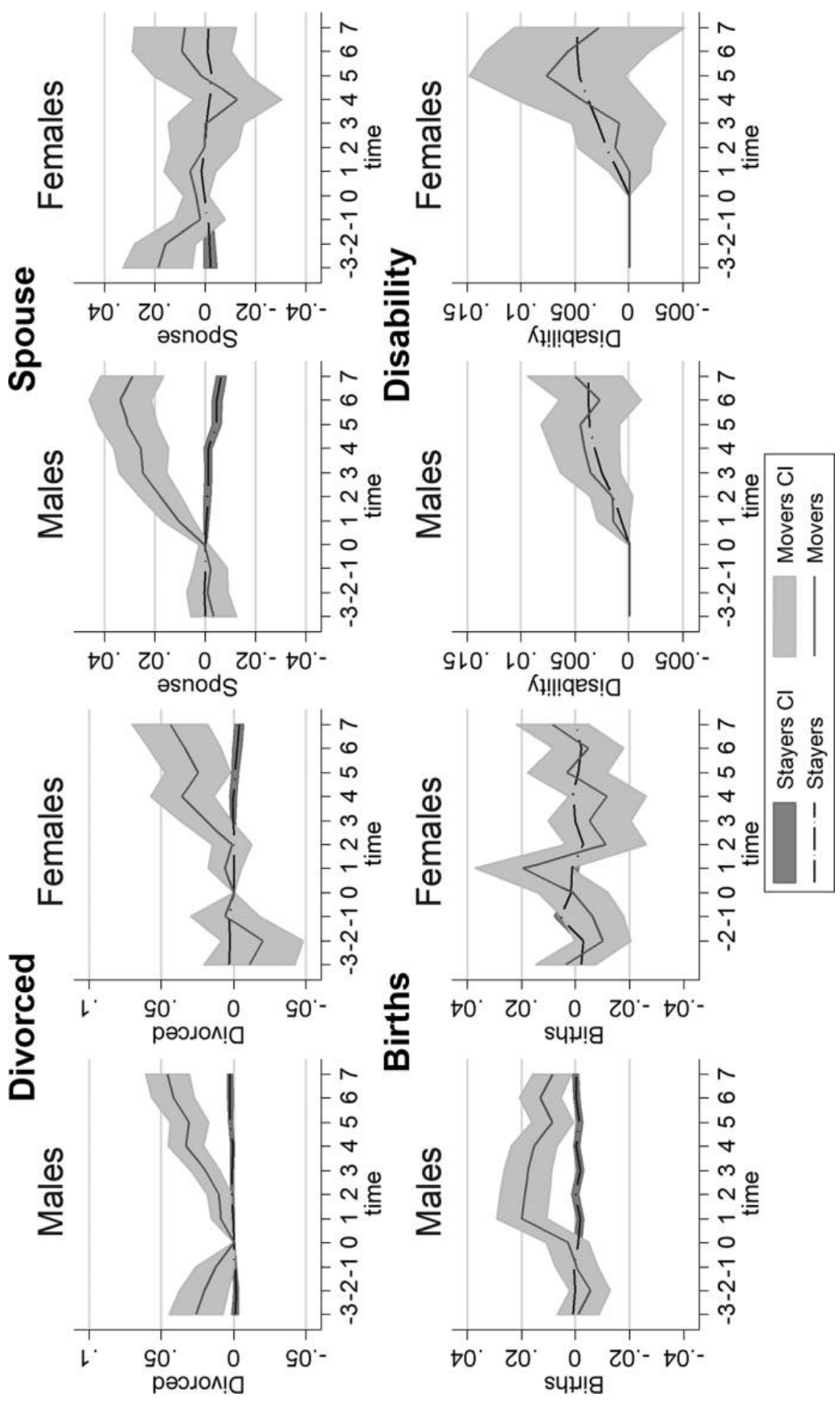

This content downloaded from 130.233.216.094 on May 04, 2018 01:26:34 AM

All use subject to University of Chicago Press Terms and Conditions (http://www.journals.uchicago.edu/t-and-c). 
four outcomes: (i) divorce, (ii) cohabitation with a married or unmarried partner, (iii) fertility, and (iv) receiving a disability pension. Divorce is defined as not living together with your base year partner. In all four regressions, the comparison group is all nondisplaced workers (i.e., both movers and stayers). Figure 7 shows that being a displaced mover is associated with an increased likelihood of becoming divorced. Being a displaced stayer is not associated with divorce; hence, the finding for displaced movers may primarily reflect a link between divorce and migration rather than between divorce and displacement. With respect to cohabitation, we find that being a male displaced mover is associated with an increasing likelihood of cohabitation, while this is not the case for displaced female movers or displaced stayers. This pattern resembles what we found with respect to divorce and may suggest that males are more likely to move than females when families or relationships form or break up. Next, we see that being a displaced male mover is associated with fertility, while there is no such association for displaced female movers or for displaced stayers. One explanation for the difference between men and women may be that male displacement represents a larger decline in the opportunity cost of moving than female displacement. Hence, for couples who are about to have children, male displacement is a more important window of opportunity for relocation. In addition, we should bear in mind that in the male display we use couples where the male is employed full time in years $t-3$ to $t$, and in the female display we use couples where the woman is employed full time in years $t-3$ to $t$. It may well be that couples where the woman is well attached to the labor market are different from couples where the man is well attached to the labor market. Finally, with respect to disability, we find a strong effect for both displaced movers and displaced stayers. This result is consistent with previous analyses showing that job loss has a negative effect on health-related

FIG. 7.- - How job displacement relates to fertility, cohabitation, divorce, and disability. Each panel plots regression coefficients and $90 \%$ confidence intervals (CIs) obtained from separate ordinary least squares regressions for each time period. The dependent variable is an indicator for (i) divorce, (ii) cohabitation with a married or unmarried partner, (iii) giving birth, and (iv) receiving a disability pension. The divorce regression is run on a sample that only includes workers who were cohabiting in the base year. The following base year control variables are included but not reported: age (dummies); education (three categories); tenure; marital status; having a partner (not in the divorce and cohabitation regression); schoolage children; children under school age; parent in the region; sibling in the region; both parent and sibling in the region; younger siblings; plant size (numerical); plant size under 20; plant size interacted with plant size under 20; in school at year $b-4$; in school at year $b-5$; real earnings in year $b-4$; real earnings in year $b-5$; employment months in year $b-4$; employment months in year $b-5$; living in the base year region in year $b-4$, year $b-3$, and year $b-2$; and region, industry, and base year dummies. 
outcomes (see n. 5). In sum, people use the changing conditions following job loss to make mobility and family decisions. These correlated shocks may partly explain earnings losses following a regional move.

\section{Concluding Remarks}

It is well established that there are large and persistent differences in unemployment rates and economic activity across different locations. We also know that individuals who lose their jobs for exogenous reasons suffer long-lasting and permanent earnings losses. Much less is known about the reasons for these losses and why individuals with severe losses do not move to locations with better employment opportunities. We have analyzed the geographic mobility of workers after permanent job loss and investigated factors that influence workers' migration decisions. We have based the analysis on a framework where workers' or families' decisions to move after job loss depends on three types of factors: (i) the returns to mobility in terms of employment and earnings; (ii) location-specific amenities, such as family ties; and (iii) personal events related to family formation and health. Our rich Norwegian register data include information on workers', spouses', and parents' characteristics, including location, employment history, disability, and fertility. This allows us to investigate the factors that influence mobility in great detail.

Our results show that noneconomic factors strongly influence the migration decisions for workers who experience job loss. Workers are less likely to move away from regions where their parents or siblings live, and some move back home after a job loss. Mobility decisions after job loss are also related to family-forming decisions, such as divorce, birth, and cohabitation. We show that earnings losses after job displacement differ sharply among groups of workers who have different motives for moving. On average, displaced workers who move to a new region after job loss suffer larger income losses than displaced stayers, but the difference between displaced movers and displaced stayers is driven entirely by workers who move to rural regions and to regions where they have family.

\section{References}

Abramitzky, Ran, Leah Platt Boustan, and Katherine Eriksson. 2012. Europe's tired, poor, huddled masses: Self-selection and economic outcomes in the age of mass migration. American Economic Review 102, no. 5:1832-56.

Alesina, Alberto F., Yann Algan, Pierre Cahuc, and Paola Giuliano. 2015. Family values and the regulation of labor. Lournal of the European Economic Association 13, no. 4:599-630.

Autor, David H., David Dorn, and Gordon H. Hanson. 2013. The China syndrome: Local labor market effects of import competition in the United States. American Economic Review 103, no. 6: 2121-68. 
Balsvik, Ragnhild, Sissel Jensen, and Kjell G. Salvanes. 2015. Made in China, sold in Norway: Local labor market effects of an import shock. Lournal of Public Economics 127 (July): 137-44.

Bhuller, Manudeep S. 2009. Inndeling av Norge i arbeidsmarkedsregioner, Notater 2009/24. Statistics Norway.

Black, Sandra E., Paul J. Devereux, and Kjell G. Salvanes. 2015. Losing heart? The effect of job displacement on health. ILR Review 68, no. 4:833-61.

Blanchard, Olivier J., and Lawrence F. Katz. 1992. Regional evolutions. Brookings Papers on Economic Activity 23, no. 1:1-76.

Blomquist, Glenn C., Mark C. Berger, and John P. Hoehn. 1988. New estimates of quality of life in urban areas. American Economic Review 78, no. 1:89-107.

Boman, Anders. 2011. Does migration pay? Earnings effects of geographic mobility following job displacement. Lournal of Population Economics 24, no. 4:1369-84.

Borjas, George J. 1987. Self-selection and the earnings of immigrants. American Economic Review 77, no. 4:531-53.

1991. Immigration and self-selection. In Immigration, trade, and the labor market, ed. J. M. Abowd and R. B. Freeman, 29-76. Chicago: University of Chicago Press.

Borjas, George J., Stephen G. Bronars, and Stephen J. Trejo. 1992. Selfselection and internal migration in the United States. Iournal of Urban Economics 32, no. 2:159-85.

Browning, Martin, and Eskil Heinesen. 2012. Effect of job loss due to plant closure on mortality and hospitalization. Lournal of Health Economics 31, no. 4:599-616.

Charles, Kerwin Kofi, and Melvin Stephens Jr. 2004. Disability, job displacement, and divorce. Lournal of Labor Economics 22, no. 2:489-522.

Chen, Yong, and Stuart S. Rosenthal. 2008. Local amenities and life-cycle migration: Do people move for jobs or fun? Iournal of Urban Economics 64, no. 3:519-37.

Couch, Kenneth A., and Dana W. Placzek. 2010. Earnings losses of displaced workers revisited. American Economic Review 100, no. 1:57289.

Crump, Richard K., V. Joseph Hotz, Guido W. Imbens, and Oscar A. Mitnik. 2009. Dealing with limited overlap in estimation of average treatment effects. Biometrika 96, no. 1:187-99.

DaVanzo, Julie. 1978. Does unemployment affect migration? Evidence from micro data. Review of Economics and Statistics 60, no. 4:504-14.

Davis, Steven J., and Till von Wachter. 2011. Recessions and the costs of job loss. Brooking Papers on Economic Activity, Fall, 1-72.

Del Bono, Emilia, Andrea Weber, and Rudolf Winter-Ebmer. 2012. Clash of career and family: Fertility decisions after job displacement. Lournal of the European Economic Association 10, no. 4:659-83. 
Eliason, Marcus. 2012. Lost jobs, broken marriages. Lournal of Population Economics 25, no. 4:1365-97.

Eliason, Marcus, and Donald Storrie. 2006. Latent or lasting scars: Swedish evidence on the long-term effects of job displacement. Iournal of Labor Economics 24, no. 4:831-56.

Glaeser, Edward L., and David C. Mare. 2001. Cities and skills. Lournal of Labor Economics 19, no. 2:316-42.

Glaser, Karen F., and Cecilia Tomassini. 2000. Proximity to children: A comparison of Britain and Italy. Gerontologist 40, no. 6:729-37.

Greenwood, Michael J. 1997. The internal migration in developed countries. In Handbook of population and family economics, ed. M. R. Rosenzweig and O. Stark, vol. 1, pt. B, chap. 12, 647-720. Amsterdam: Elsevier.

Gregg, Paul, Stephen Machin, and Alan Manning. 2004. Mobility and joblessness. In Seeking a premier economy: The economic effects of British economic reforms, 1980-2000, ed. David Card, Richard Blundell, and Richard B. Freeman, chap. 9. Chicago: University of Chicago Press; Cambridge, MA: National Bureau of Economic Research.

Gyourko, Joseph, and Joseph Tracy. 1991. The structure of local public finance and the quality of life. Iournal of Political Economv 99, no. 4:774806.

Huttunen, Kristiina, and Jenni Kellokumpu. 2016. The effect of job displacement on couples' fertility decisions. Iournal of Labor Economics 34, no. 2:403-42.

Huttunen, Kristiina, Jarle Møen, and Kjell G. Salvanes. 2011. How destructive is creative destruction? Effects of job loss on job mobility, withdrawal and income. Lournal of the European Economic Association 9, no. 5:84070.

Jacobson, Louis S., Robert J. LaLonde, and Daniel G. Sullivan. 1993. Earnings losses of displaced workers. American Economic Review 83, no. 4: 685-709.

Kennan, John, and James R. Walker. 2011. The effect of expected income on individual migration decisions. Econometrica 79, no. 1:211-51.

Konrad, Kai A., Harald Künemund, Kjell Erik Lommerud, and Julio R. Robledo. 2002. Geography of the family. American Economic Review 92, no. 4:981-98.

Kramarz, Francis, and Oskar Nordström Skans. 2014. When strong ties are strong: Networks and youth labour market entry. Review of Economic Studies 81, no. 3:1164-1200.

Kroft, Kory, Fabian Lange, Matthew J. Notowidigdo, and Lawrence F. Katz. 2016. Long-term unemployment and the Great Recession: The role of composition, duration dependence, and nonparticipation. Iournal of Labor Economics 34, suppl.:S7-S54.

Lin, Ge, and Peter A. Rogerson. 1995. Elderly parents and the geographic availability of their adult children. Research on Aging 17, no. 3:303-31. 
Lindo, Jason. 2010. Are children really inferior goods? Evidence from displacement-driven income shocks. Lournal of Human Resources 45, no. 2:301-27.

Machin, Stephen, Kjell G. Salvanes, and Panu Pelkonen. 2012. Education and mobility. Iournal of the European Economic Association 10, no. 2: 417-50.

Mincer, Jacob. 1978. Family migration decisions. Iournal of Political Economv 86, no. 5:749-73.

Molloy, Raven, Christopher L. Smith, and Abigail Wozniak. 2011. Internal migration in the United States. Lournal of Economic Perspectives 25, no. 3: 173-96.

Moretti, Enrico. 2011. Local labor markets. In Handbook of labor economics, ed. David Card and Orley Ashenfelter, vol. 4, pt. B, chap. 14, 1237 313. Amsterdam: Elsevier.

Pekkala, Sari, and Tervo Hannu. 2002. Unemployment and migration: Does moving help? Scandinavian Iournal of Economics 104, no. 4:621-39.

Pissarides, Christopher A., and Jonathan Wadsworth. 1989. Unemployment and the inter-regional mobility of labour. Economic Iournal 99, no. 397:739-55.

Rainer, Helmut, and Thomas Siedler. 2009. O brother, where art thou? The effects of having a sibling on geographic mobility and labour market outcomes. Economica 76, no. 303:528-56.

Rege, Mari, Kjetil Telle, and Mark Votruba. 2009. The effect of plant downsizing on disability pension utilization. Lournal of the European Economic Association 7, no. 4:754-85.

Roback, Jennifer. 1982. Wages, rents and the quality of life. Lournal of $\mathrm{PO}_{\mathrm{O}}$ litical Economv 90, no. 6:1257-78.

Roy, Andrew D. 1951. Some thoughts on the distribution of earnings. $\mathrm{Ox}-$ ford Economic Papers 3, no. 2:135-46.

Saks, Raven E., and Abigail Wozniak. 2011. Labor reallocation over the business cycle: New evidence from internal migration. Lournal of Labor Economics 29, no. 4:697-739.

Schmieder, Johannes F., Till von Wachter, and Stefan Bender. 2009. The long-term impact of job displacement in Germany during the 1982 recession on earnings, income, and employment. Discussion Paper no. 091007, Department of Economics, Columbia University, New York.

Sjaastad, Larry A. 1962. The costs and returns of human migration. Iournal of Political Economy 70, no. 5:80-93.

Sullivan, Daniel, and Till von Wachter. 2009. Job displacement and mortality: An analysis using administrative data. Ouarterly Iournal of Economics 124 , no. 3:1265-306. 